\title{
Pendampingan Orangtua Balita Fase Pemerolehan Bahasa di Posyandu Mawar 6 Kelurahan Noyontaansari Kota Pekalongan Guna Mendukung Kota Layak Anak
}

\author{
Dina Nurmalisa*1, Afrinar Pramitasari², Ariesma Setyarum³, Hanindya Restu \\ Aulia 4
}

\author{
1,2,3,4Pendidikan Bahasa dan Sastra Indonesia, Fakultas Keguruan dan Ilmu Pendidikan, Universitas \\ Pekalongan, Indonesia \\ *e-mail: dina.pbsi.unikal@gmail.com ${ }^{1}$, nurasyifaa2018@gmail.com ${ }^{2}$, rizma2208@gmail.com ${ }^{3}$, \\ hanindyaunikal@gmail.com ${ }^{4}$
}

\begin{abstract}
Abstrak
Pemerolehan dan pengembangan bahasa bagi anak usia dini salah satunya berfungsi sebagai alat pengembangan intelektual anak yang akan menentukan perkembangan intelektual anak selanjutnya. Tujuan kegiatan pengabdian kepada masyarakat ini adalah memberikan penyuluhan dan pendampingan kepada orangtua balita masa pemerolehan bahasa anak di posyandu mawar 6 Kota Pekalongan untuk mencegah speech delay. Kegiatan PKM ini dilakukan dalam tiga tahap yaitu perencanaan, pelaksanaan, dan evaluasi. Metode yang digunakan adalah penyuluhan dan pendampingan. Penyuluhan dengan strategi kronologis, yaitu memberikan pengetahuan kepada warga posyandu dalam mendampingi anak pada fase pemerolehan bahasa secara bertahap. Pendekatan yang digunakan dalam kegiatan ini adalah diskusi dan participant active learning, yaitu warga berperan aktif dalam praktik. Evaluasi dilaksanakan dua tahap, yaitu evaluasi antarwarga posyandu dan evaluasi hasil pendampingan oleh tim pengabdian. Hasil yang dicapai dalam kegiatan PKM ini adalah 1) meningkatnya pengetahuan dan pemahaman orangtua tentang pentingnya mendampingi dan menstimulus anak pada masa pemerolehan bahasa, 2) meningkatnya motivasi orangtua untuk memberikan pola asuh yang tepat kepada anak pada masa pandemi Covid-19, dan 3) bertambahnya jumlah kosakata balita yang diduga mengalami keterlambatan berbicara di posyandu mawar 6 Kelurahan Noyontaansari. Kegiatan pengabdian kepada masyarakat yang dilakukan oleh tim mendapatkan respon yang baik dari warga dan pengurus posyandu.
\end{abstract}

Kata kunci: Pemerolehan Bahasa, Posyandu, Speech Delay

\begin{abstract}
The acquisition and development of language for early childhood has the function as a tool for children's intellectual development which will determine the subsequent intellectual development of children. The purpose of Pengabdian Kepada Masyarakat (PKM) is to provide counseling and assistance to parents of toddlers during the acquisition of children's language at Posyandu Mawar 6 Pekalongan City to prevent speech delay. This PKM activity was carried out in three stages, namely planning, implementation, and evaluation. The methods used in this PKM were counseling and mentoring. Counseling with a chronological strategy is providing knowledge to posyandu residents in assisting children in the gradual language acquisition phase. The approaches used in this activity were discussion and participant active learning, where residents take an active role in practice. The evaluation was held in two stages, they were the evaluation between Posyandu residents and the evaluation of the results of assistance by the service team. The results achieved in this PKM activity were 1) increasing the knowledge and understanding of parents about the importance of accompanying and stimulating children during language acquisition, 2) increasing the motivation of parents to provide appropriate parenting to children during the COVID-19 pandemic, and 3 ) increasing the number of vocabulary for toddlers who are suspected of having delays in speaking at the Posyandu Mawar 6, Noyontaansari Village. PKM activity which was done by the team had a good response from residents and posyandu administrators.
\end{abstract}

Keywords: Language Acquisition, Posyandu, Speech Delay

\section{PENDAHULUAN}

Golden age atau periode emas adalah tahapan pertumbuhan dan perkembangan yang paling penting pada masa awal kehidupan anak. Anak usia 0-6 tahun atau biasa disebut golden 
age merupakan masa sensitif bagi anak untuk menerima berbagai upaya pengembangan seluruh potensi yang ada. Perhatian dan dukungan yang baik dari orang tua serta lingkungan kondusif akan dapat mengoptimalkan pertumbuhan dan perkembangan anak (Sumiyati, 2018). Pada masa ini, pemberian stimulus atau rangsangan untuk segala aspek perkembangan anak mempunyai peran yang penting. Apabila pada usia golden age anak tidak diberikan stimulus yang mencukupi dan lingkungan yang mendukung, maka akan berdampak pada tumbuh kembang anak baik secara fisik, kognitif ataupun kemampuan berbahasa yang dimiliki anak. Fase pemerolehan bahasa juga terjadi pada masa golden age, sehingga pola asuh dan pendampingan orangtua sangat diperlukan untuk membantu tumbuh kembang anak agar lebih baik.

Pemerolehan bahasa adalah proses penguasaan bahasa yang dilakukan oleh anak secara natural ketika ia belajar bahasa ibunya (Dardjowidjodjo, 2003:225). Menurut teori yang didasarkan pada kesemestaan kognitif, bahasa diperoleh berdasarkan struktur-struktur kognitif deriamotor. Struktur itu diperoleh kanak-kanak melalui interaksi dengan benda-benda atau orang-orang di sekitarnya. Tahap 5 tahun pertama dari kelahiran anak adalah masa penting pemerolehan bahasa yang harus didampingi dan distimulus oleh orangtua dan lingkungan. Karena perkembangan anak di tahap selanjutnya akan dipengaruhi oleh pemenuhan tugas perkembangan anak di tahap sebelumnya (Hockenberry dan Wilson 2009).

Pengecekan tumbuh kembang anak selalu dipantau dalam kegiatan posyandu (Pos Pelayanan Terpadu) yang merupakan upaya pemerintah untuk memudahkan masyarakat dalam memperoleh pelayanan kesehatan ibu dan anak. Namun, kegiatan posyandu lebih fokus untuk memantau tumbuh kembang fisik anak seperti pemenuhan gizi anak, pertambahan berat badan, dan tinggi badan anak sesuai dengan grafik KMS dan jarang memantau perkembangan bahasa anak balita. Padahal pemerolehan dan perkembangan bahasa pada anak usia dini salah satunya berfungsi sebagai alat pengembangan intelektual anak yang akan menentukan perkembangan intelektual anak selanjutnya. Hal tersebut sesuai dengan pendapat Meliana (2015) yang mengungkapkan bahwa perkembangan bahasa merupakan salah satu aspek yang sangat penting dalam perkembangan anak, karena perkembangan bahasa akan berpengaruh terhadap aspek perkembangan lainnya. Kemampuan bahasa akan mampu membangun kemampuan kognitif, social, emosional pada anak. Sehingga fase pemerolehan bahasa anak adalah fase yang penting untuk dipantau dan didampingi agar anak tidak mengalami keterlambatan berbicara (speech delay).

Posyandu Mawar 6 melaksanakan kegiatan rutin bulanan sebagaimana Posyandu pada umumnya. Kegiatan tersebut dilaksanakan setiap bulan pada tanggal 16. Adapun kegiatan berkala yang dilakukan oleh Posyandu ini adalah: 1) pengecekan tumbuh kembang anak, kegiatan ini dilakukan setiap bulan untuk memantau pertumbuhan fisik anak, seperti penimbangan balita 2) pemasangan dan pemantauan stiker P4K yang bertujuan untuk memudahkan tim posyandu dalam melakukan pengecekan terhadap kader posyandu yang tengah memiliki balita 3) pemeriksaan berkala jentik nyamuk 4) pemberian makanan tambahan pada balita 5) Pemberian vitamin A pada bulan Februari dan Agustus, dan 6) pemantauan UPGK (Upaya Perbaikan Gizi Keluarga).

Berdasarkan hasil diskusi dengan ketua posyandu mitra, permasalahan yang dihadapi adalah kurangnya pengetahuan orang tua terhadap fase tumbuh kembang anak, terutama dalam hal pemerolehan bahasa. Meskipun pemerolehan bahasa terjadi secara alamiah, namun perlu dukungan keluarga dalam menciptakan suasana komunikasi dalam keluarga yang kondusif dan ramah anak. Selain itu, masa pandemi covid-19 juga mempengaruhi pola asuh orangtua terhadap anak. Hal ini disebabkan banyak orang tua yang lebih fokus pada pemenuhan kebutuhan, seperti kegiatan ibu dalam membantu mencari nafkah untuk keluarga, sehingga waktu yang diberikan untuk anak berkurang. Selain itu, pembatasan interaksi dan kegiatan sekolah daring menyebabkan anak lebih banyak menghabiskan waktu di rumah dengan hanphone dan gawai. Kesibukan dengan gawai ini berpengaruh pada keinginan anak untuk berinteraksi dengan keluarga yang lain berkurang dan mengalami ketergantungan pada tontonan di layar gawai. 
Selain itu, berdasarkan observasi awal, diketahui bahwa ada beberapa kasus keterlambatan berbicara (Speech delay) pada anak di posyandu mawar 6 Kelurahan Noyontaansari. Speech Delay atau keterlambatan bicara merupakan istilah umum merujuk pada proses keterlambatan bicara dan berbahasa yang tidak sesuai dengan usia perkembangan anak. Menurut Sawyer (2017) anak dengan keterlambatan berbicara tidak memiliki motivasi yang kuat untuk berbicara dibandingkan dengan anak yang normal, kondisi ini berlangsung pada usia 2 tahun awal kehidupan. Tanda ini sering diabaikan oleh orangtua karena beberapa orang tua menganggap speech delay sebagai kondisi normal atau hal yang biasa dialami dalam proses tumbuh kembang anak. Padahal terlambat bicara jika dibiarkan dan tidak ditangani dengan rujukan ahli bisa menjadi satu gangguan serius pada anak

Salah satu permasalahan yang dikeluhkan warga pada saat tim pengabdian melakukan observasi adalah tumbuh kembang anak dalam hal pemerolehan bahasa. Anak-anak mulai jarang berkomunikasi dengan orang lain. Mereka asyik dengan dunianya sendiri, terlebih lagi ketika masa pandemi covid-19 di mana interaksi dengan orang lain dibatasi. Pada masa seperti ini, keluarga menjadi narasumber utama dalam proses pengetahuan anak terhadap cara berkomunikasi. Selain itu, penggunaan gawai yang biasanya menjadi alternatif orang tua untuk menenangkan anak membawa pengaruh kurang baik. Padahal, pola asuh orangtua sangat mempengaruhi perkembangan bicara anak, seperti diungkapkan oleh Sacikala dan Cecil (2016) yang menyatakan bahwa keterikatan (bonding) orangtua dengan anak sebagai lini pertama role model di rumah memberikan pengaruh besar terhadap perkembangan bicara anak serta apa pun yang ingin anak ungkapkan.

Berdasarkan masalah-masalah yang ada di posyandu mawar 6, pendampingan yang diberikan oleh tim PKM bertujuan untuk memberikan penyuluhan kepada orangtua balita agar mendampingi dan menstimulus anak-anak untuk berkomunikasi dua arah. Selain itu, tujuan kegiatan PKM ini juga untuk mencegah speech delay atau keterlambatan berbahasa pada anak karena pemerolehan dan pengembangan bahasa bagi anak usia dini salah satunya berfungsi sebagai alat pengembangan intelektual anak yang akan menentukan perkembangan intelektual anak selanjutnya. Hal tersebut sejalan dengan pendapat Suhartono (2005: 13-14) yang menyatakan bahwa pemerolehan bahasa sangat berperan bagi anak usia dini sebagai sarana agar anak mampu membaca dan menulis karena seseorang dapat menyampaikan keinginan, pendapat, ide atau gagasan kepada orang lain melalui bahasa.

\section{METODE}

Kegiatan PKM dilaksanakan bekerjasama dengan posyandu mawar 6 Kelurahan Noyontaansari Kota Pekalongan. Sedangkan waktu pelaksanaan dimulai pada bulan Oktober sampai dengan Desember 2021. Kegiatan pengabdian ini dilaksanakan dalam 3 tahap, yaitu perencanaan, pelaksanaan, dan evaluasi. Kegiatan yang dilakukan tim pada tahap perencanaan adalah:

a. Tim PKM melakukan mengumpulkan data mengenai permasalahan yang dihadapi oleh posyandu mitra.

b. Menentukan solusi yang ditawarkan.

c. Setelah mendapatkan data-data awal, tim PKM melakukan penyusunan materi penyuluhan dan langkah-langkah pendampingan.

Pada tahap pelaksanaan, tim PKM melaksanakan beberapa kegiatan yaitu:

a. Pemberian materi pemerolehan bahasa pada anak dan pendampingan pola asuh dalam keluarga.

b. Penyuluhan dengan strategi kronologis, yaitu memberikan pengetahuan kepada warga posyandu dalam mendampingi anak pada fase pertumbuhan yang berkenaan dengan pemerolehan bahasa secara bertahap.

c. Pendekatan yang digunakan dalam kegiatan ini adalah participant active learning, yaitu warga berperan aktif dalam praktik. 
d. Metode yang digunakan dalam proses penyuluhan dan pendampingan adalah ceramah, diskusi, praktik, dan sharing session.

Tahap terakhir adalah evaluasi, yaitu evaluasi antarwarga posyandu dan evaluasi hasil pendampingan oleh tim pengabdian. Adapaun rangkaian kegiatan PKM disajikan pada Gambar 1.

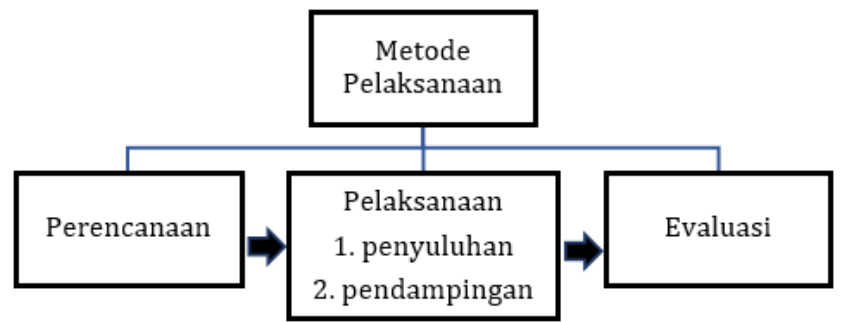

Gambar 1. Tahap pelaksanaaan kegiatan PKM

Adapun luaran yang diharapkan dari kegiatan ini adalah:

a. Meningkatnya pengetahuan dan pemahaman orangtua tentang pentingnya mendampingi dan menstimulus anak pada masa pemerolehan bahasa

b. Meningkatnya motivasi orangtua untuk menstimulus anak pada masa pemerolehan bahasa

c. Bertambahnya jumlah kosakata balita yang diduga mengalami keterlambatan berbicara di posyandu mawar 6 Kelurahan Noyontaansari.

Untuk mengetahui ketercapaian luaran kegiatan pengabdian ini dilakukan penyebaran angket kepada peserta di akhir kegiatan.

\section{HASIL DAN PEMBAHASAN}

\subsection{Survei Pendahuluan dan Persiapan Materi Kegiatan Pengabdian}

Kegiatan PKM ini diawali dengan diskusi antara tim PKM Unikal dengan pengurus posyandu Mawar 6 Kelurahan Noyontaansari Kota Pekalongan. Berdasarkan hasil diskusi, diperoleh permasalahan yang muncul dalam proses tumbuh kembang anak di posyandu mawar 6 yaitu ada beberapa kasus balita yan mengalami speech delay. Selanjutnya, tim PKM dan pengurus posyandu sepakat untuk melaksanakan kegiatan penyuluhan dan pendampingan.

Pelaksanaan pendampingan orangtua balita masa pemerolehan bahasa di Kelurahan Noyontaansari Kota Pekalongan dilaksanakan selama tiga bulan yaitu dari bulan Oktober sampai dengan Desember 2021. Peserta atau anggota posyandu mawar 6 terdiri atas dua RT yaitu 50 orangtua yang mempunyai balita. Jadwal kegiatan penyuluhan dan pendampingan dapat dilihat pada tabel 1 berikut.

Tabel 1. Jadwal kegiatan penyuluhan dan pendampingan

\begin{tabular}{|c|c|c|c|}
\hline No. & Hari/tanggal & Narasumber & Materi Penyuluhan \\
\hline 1. & $\begin{array}{l}\text { Sabtu, } 16 \text { Oktober } \\
2021\end{array}$ & $\begin{array}{l}\text { Afrinar Pramitasari, } \\
\text { M.Pd }\end{array}$ & $\begin{array}{l}\text { 1. Tahap-tahap pemerolehan } \\
\text { perkembangan bahasa anak } \\
\text { 2. Pendampingan }\end{array}$ \\
\hline 2. & $\begin{array}{l}16 \\
\text { per } 2021\end{array}$ & $\begin{array}{l}\text { 1. Dr.Dina Nurmalisa, } \\
\text { S.S., M.Hum. } \\
\text { 2. Hanindya Restu } \\
\text { Aulia, M.Pd. }\end{array}$ & $\begin{array}{l}\text { 1. Deteksi keterlambatan bahasa pada } \\
\text { anak (Speech delay), } \\
\text { 2. Penyebab dan cara mengatasi speech } \\
\text { delay sedini mungkin } \\
\text { 3. Pendampingan }\end{array}$ \\
\hline 3. & $\begin{array}{l}\text { Kamis, } 16 \\
\text { Desember } 2021\end{array}$ & $\begin{array}{l}\text { Ariesma Setyarum, } \\
\text { S.Pd., M.Hum. }\end{array}$ & $\begin{array}{l}\text { 1. Pola pengasuhan positif pada masa } \\
\text { pandemi covid- } 19 \\
\text { 2. Pendampingan }\end{array}$ \\
\hline
\end{tabular}




\subsection{Pemaparan Materi "Tahap-Tahap Pemerolehan dan Perkembangan Bahasa pada Anak" dan Pendampingan Bulan Pertama}

Pertemuan pertama dilaksanakan pada bulan Oktober 2021 diawali dengan pemberian materi tentang tahap-tahap pemerolehan bahasa anak yang meliputi tahap refleks, babling, lulling, echolia, dan true speech. Pemerolehan bahasa pada anak dipengaruhi oleh beberapa faktor, di antaranya faktor alamiah dan faktor perkembangan kognitif. Pemerolehan bahasa pada anak bersifat alamiah, dengan proses yang bisa dirangsang ataupun kemampuan mereka dalam menangkap apa yang terjadi di sekitarnya. Sementara itu, perkembangan bahasa seseorang beriringan dengan perkembangan kognitifnya. Dalam prosesnya, pemerolehan bahasa dibantu oleh perkembangan kognitif, sebaliknya kemampuan kognitif akan berkembang dengan bantuan bahasa. Keduanya berkembang dalam lingkup interaksi sosial. Selain itu dijelaskan pula perkembangan bahasa anak usia 0-5 tahun oleh narasumber seperti pada Gambar 2 berikut.

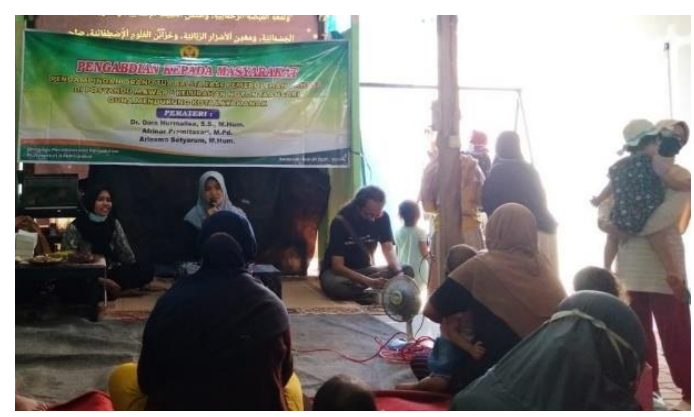

Gambar 2. Pemaparan materi pemerolehan dan perkembangan bahasa anak

Gambar 2 merupakan kondisi ketika pemaparan materi tentang pemerolehan dan perkembangan bahasa anak oleh narasumber. Peserta sangat antusias dalam menyimak materi yang disampaikan oleh narasumber. Peserta mengamati tahap-tahap pemerolehan bahasa anak dengan perkembangan bahasa pada anak-anak mereka. Setelah narasumber selesai menyampaikan materi, tim PKM dan warga posyandu mawar 6 melaksanakan diskusi dan tanya jawab seputar tumbuh kembang anak khususnya perkembangan bahasa anak. Warga posyandu mawar 6 antusias dalam diskusi dan banyak warga yang bertanya tentang perkembangan bahasa anak-anak mereka. Setelah selesai penyuluhan, dilanjutkan dengan pendampingan orangtua balita fase pemerolehan bahasa di posyandu mawar 6. Pendampingan bulan pertama ini diikuti oleh 40 orangtua balita fase pemerolehan bahasa. Selama pendampingan, tim PKM dan peserta melakukan diskusi dan sharing sesion.

\subsection{Pemaparan Materi “Deteksi Dini Speech Delay pada Anak" dan Pendampingan Bulan kedua}

Pertemuan kedua dilaksanakan pada bulan November 2021 diawali dengan pemaparan materi tentang deteksi dini speech delay pada anak, penyebab dan cara mengatasi speech delay. Peserta juga sangat antusias dengan materi yang disampaikan oleh narasumber. Setelah narasumber selesai menyampaikan materi, dilaksanakan diskusi dan tanya jawab. Beberapa orangtua balita bertanya tentang perkembangan bahasa anak-anak mereka dan apakah anakanak mereka mengalami speech delay atau tidak. Selama kurang lebih satu jam tim PKM yang dibantu oleh mahasiswa melaksanakan pendampingan orangtua balita di posyandu mawar 6 seperti pada Gambar 3.

Gambar 3 memperlihatkan kegiatan diskusi dan pendampingan dengan orangtua balita yang diduga mengalami speech delay. Orangtua mengeluhkan bahwa di usia anak 2 tahun, anak tidak merespon jika dipanggil namanya dan kosakata anak juga belum banyak. Padahal sesuai dengan teori pemerolehan bahasa dan perkembangan bahasa anak, anak usia 2 tahun seharusnya sudah bisa mengucapkan kalimat sederhana, sudah dapat memahami perintah dan merespon jika dipanggil. 


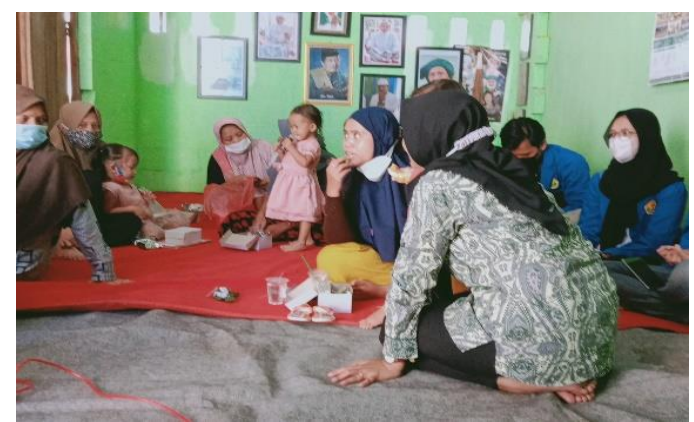

Gambar 3. Pendampingan speech delay pada anak

Tim PKM memberikan cara-cara mengatasi speech delay pada anak salah satunya adalah memberikan motivasi kepada orangtua agar menstimulus anaknya agar berbicara. Orangtua dapat mulai memberikan motivasi kepada anak untuk berbicara sejak dini. Sejak anak lahir orangtua diimbau untuk mengajak anak untuk berbicara. Misalnya ketika sedang memandikan anak dan mengganti popok anak sambil mengajak berbicara anak. Walaupun anak bayi belum dapat merespon, namun mereka menyimpan kosakata yang mereka dengar setiap hari. setelah anak mulai bisa berbicara 1-2 kata di usia 1-2 tahun, pemberian motivasi ini dapat dilakukan dengan metode bermain peran (siska, 2011). Dengan memerankan suatu tokoh, memberikan wahana kepada anak untuk mengekspresikan perasaan anak kepada orangtua dan meningkatkan kepercayaan diri anak. Peningkatan kepercayaan diri akan meningkatkan motivasi anak dalam berbicara (Hoover et al., 2011).

Selain itu, tim PKM juga memberikan saran kepada orangtua untuk selalu memberikan apresiasi pada setiap kemampuan anak dengan memuji atau memberikan hadiah kepada anak. Hal yang paling penting dari semua upaya tersebut adalah membatasi anak untuk bermain handphone dan menonton televisi untuk anak di bawah usia 2 tahun. Beberapa orangtua tidak menyadari bahwa kebiasaan menonton televisi dan bermain handphone yang terlalu sering dapat membuat anak mengalami speech delay.

\subsection{Pemaparan Materi “Pola Pengasuhan Positif” dan Pendampingan Bulan Ketiga}

Pendampingan bulan ketiga dilaksanakan pada bulan desember 2021 sesuai jadwal yang sudah ditentukan. Kegiatan diawali dengan pemaparan materi tentang pola pengasuhan positif pada anak di masa pandemi covid-19, dilanjutkan dengan diskusi dan tanya jawab, dan diakhiri dengan kegiatan pendampingan. Peserta sangat antusias dengan materi seperti terlihat pada Gambar 4 berikut.

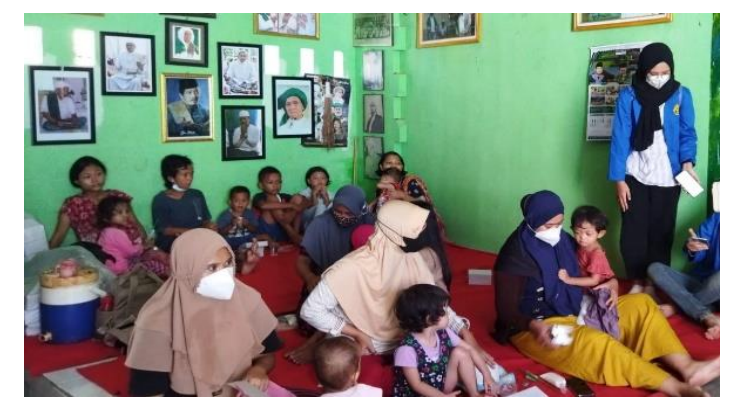

Gambar 4. Antusias peserta dalam pendampingan

Beberapa orangtua mengelukan anak-anak mereka kurang responsif dan lebih suka melihat televisi dan bermain gawai. Narasumber memberikan tips pola asuh positif pada masa pandemi covid-19 agar anak tidak ketergantungan dengan gawai dan tayangan televisi karena penggunaan gawai yang berlebihan dapat menyebab kan anak mengalamai keterlambatan berbicara. Tim PKM juga mengimbau orangtua agar mendampingi anak-anak mereka ketika anak-anak bermain handphone atau menonton televisi agar tercipta komunikasi dua arah. 


\subsection{Evaluasi}

Setelah dilaksanakan penyuluhan dan pendampingan selama tiga bulan, maka dilakukan evaluasi. Tim pelaksana memberikan angket kepada warga posyandu mawar 6 Keluarahan Noyontaansari untuk mengetahui respon terhadap kegiatan pengabdian kepada masyarakat yang telah dilaksanakan.

Dari hasil penyebaran angket tersebut, diketahui bahwa 1) kegiatan pendampingan orangtua balita fase pemerolehan bahasa di posyandu mawar 6 Kelurahan Noyontaansari sesuai dengan kebutuhan warga Noyontaansari. Selain itu, kegiatan ini juga sangat bermanfaat dan memberikan pemecahan masalah yang ada di posyandu mawar 6 Kelurahan Noyontaansari, 2) orangtua merasa pengetahuan dan pemahaman tentang tahap-tahap pemerolehan bahasa meningkat setelah dilaksanakan pendampingan selama tiga bulan, 3) orang tua lebih semangat mendampingi dan memotivasi anak-anak mereka untuk berbicara dalam fase pemerolehan bahasa, 4) kosakata balita masa pemerolehan bahasa meningkat selama pendampingan. Hasil penyebaran angket menunjukkan peserta memberikan respon positif yang dapat disajikan pada Tabel 2 berikut.

Tabel 2. Hasil penyebaran angket evaluasi

\begin{tabular}{lcccc}
\hline \multicolumn{1}{c}{ Aspek Respon } & $\begin{array}{c}\text { Sangat } \\
\text { setuju }\end{array}$ & Setuju & $\begin{array}{c}\text { Kurang } \\
\text { setuju }\end{array}$ & $\begin{array}{c}\text { Tidak } \\
\text { setuju }\end{array}$ \\
\hline $\begin{array}{l}\text { Kesesuaian materi dengan kebutuhan peserta } \\
\begin{array}{l}\text { Pengetahuan tentang pemerolehan bahasa } \\
\text { meningkat }\end{array}\end{array}$ & $65 \%$ & $35 \%$ & $0 \%$ & $0 \%$ \\
Motivasi orangtua meningkat & $50 \%$ & $47,5 \%$ & $2,5 \%$ & $0 \%$ \\
Kosakata balita bertambah & $60 \%$ & $40 \%$ & $0 \%$ & $0 \%$ \\
\hline
\end{tabular}

Selain itu, pengurus posyandu juga menyatakan puas dengan kegiatan pengabdian kepada masyarakat yang sudah dilaksanakan dan mengharapkan adanya kegiatan lanjutan. Sesuai dengan hasil evaluasi dari masyarakat dan pengurus posyandu mawar 6, kegiatan pengabdian ini telah mencapai tujuan kegiatan dan bahkan pengurus posyandu mengharapkan adanya kegiatan lanjutan dengan pendampingan untuk kader-kader posyandu dan PKK dan dengan durasi yang lebih panjang. Antusias warga dan pengurus posyandu ini menandakan keberhasilan pelaksanaan kegiatan pengabdian masyarakat yang telah dilaksanakan.

\section{KESIMPULAN}

Kegiatan PKM pendampingan orangtua balita masa pemerolehan bahasa di posyandu mawar 6 Kelurahan Noyontaansari Kota Pekalongan mendapat respon yang baik dari warga dan pengurus posyandu. Kegiatan PKM ini dapat meningkatkan pengetahuan orangtua tentang tahap-tahap perkembangan bahasa anak dan bahaya speech delay pada anak. Dengan adanya kegiatan PKM ini, orangtua lebih termotivasi dalam mendampingi dan menstimulus anak-anak mereka untuk berbicara sesuai dengan tahap perkembangan bahasa, sehingga dapat mencegah keterlambatan berbicara pada anak karena pemerolehan dan perkembangan bahasa bagi anak usia dini salah satunya berfungsi sebagai alat pengembangan intelektual anak yang akan menentukan perkembangan intelektual anak selanjutnya.

\section{UCAPAN TERIMA KASIH}

Penulis mengucapkan terima kasih kepada Lembaga Penelitian dan Pengabdian Kepada Masyarakat (LPPM) Universitas Pekalongan yang telah memberi dukungan terhadap kegiatan pengabdian ini. Selain itu, penulis juga mengucapkan terima kasih kepada pengurus posyandu Mawar 6 Kelurahan Noyontaansari sebagai mitra PKM yang memabntu kelancaran kegiatan pengabdian ini. 


\section{DAFTAR PUSTAKA}

Fauziah, Nurul dan Nadlifah. (2021). Strategi Orangtua dalam Membersamai Anak Belajar di Masa Pandemi Covid-19. Jurnal Ilmiah Tumbuh Kembang Anak Usia Dini, 6(2), 99-108. https://doi.org/10.14421/jga.2021.62-05

Istiqlal, Alfani Nurul. (2021). Gangguan Keterlambatan Berbicara (Speech Delay) pada Anak. Preschool, 2 (2), 206-216.

Meliana, Sari. (2015). Meningkatkan Pemahaman Orangtua dalam Menstimulasi Perkembangan Bahasa Anak Usia Dini melalui Program Parenting. Universitas Pendidikan Indonesia. http://repository.upi.edu/id/eprint/17645

Salnita. (2019). Language Acquisition for Early Childhood. Obsesi, 3(1), 265-273. https://obsesi.or.id/index.php/obsesi/article/view/160

Sasikala, S., \& Cecil, N. (2016). Parental Bonding, Peer Attachment and Psychological Well- being among Adolescents : A Mediation Analysis. Journal of Psychological Research, 11(1), 21-31.

Sawyer, J. (2017). I think I can: Preschoolers' private speech and motivation in playful versus non-playful contexts. Early Childhood Research Quarterly, 38, 84-96. http://doi.org/10.1016/j.ecresq.2016.09.004

Sumiyati. (2018). Mengenal Pertumbuhan dan Perkembangan Anak Usia Dini. Al Athfal, 1 (1), 19-36. https://www.ejournal.stainupwr.ac.id 